\title{
PARTISIPASI, TRANSPARANSI, DAN AKUNTABILITAS PERENCANAAN DAN PENGANGGARAN DANA DESA
}

\author{
Erna Hendrawati \\ hendrawati@uwks.ac.id \\ Mira Pramudianti \\ Universitas Wijaya Kusuma Surabaya \\ J1. Dukuh Kupang XXV No.54, Dukuh Kupang, Surabaya, Jawa Timur 60225
}

received: 29/8/2020; revised: 19/10/2020; approved: 28/10/2020

\begin{abstract}
This study aims are to determine the implementation of participation, transparency and accountability in planning and budgeting for village funds. Data collection techniques by observation, interviews and documentation. Respondents were village officials, BPD and community representatives in Setro village, Menganti Gresik district. Data processing techniques with editing, interpretation. Participation of the RPJMDesa and RKPDesa, village development planning deliberations involving village officials, BPD, LPMD, community leaders, community organizations, $R T, R W$, hamlet heads. Transparency, the existence of mechanisms and community access in expressing opinions, submitting responses, criticizing village administration, the RKPDesa Setro document as the basis for the preparation of the Village Budget. Accountability, RPJMDesa as a reference and direction for planning the preparation of RKPDesa, RKPDesa documents as the basis for preparing APBDesa. Participation in the 2017 APBDesa Setro, deliberations between the APBDesa drafting team and BPD, LPMD as community representatives. Transparency of the Setro Village Budget, an information banner was made at the location of the development program implementation. APBDesa Setro accountability, preparation of accountability reports as a form of accountability for the use of funds.
\end{abstract}

Keywords: participation; transparency; accountability; village funds; Setra village

\begin{abstract}
Abstrak
Penelitian ini dimaksudkan untuk mengetahui pelaksanaan partisipasi, transparansi dan akuntabilitas dalam perencanaan dan penganggaran dana desa. Teknik pengumpulan data dengan observasi, wawancara dan dokumentasi. Responden adalah perangkat desa, BPD dan perwakilan masyarakat di desa Setro, kecamatan Menganti Gresik. Teknik pengolahan data dengan editing, dan interprestasi. Partisipasi RPJMDesa dan RKPDesa, musyawarah perencanaan pembangunan desa melibatkan perangkat desa, BPD, LPMD, tokoh masyarakat, organisasi kemasyarakatan, RT,RW, kepala dusun. Transparansi, adanya mekanisme dan akses masyarakat dalam penyampaian pendapat, mengajukan tanggapan, kritik terhadap pemerintahan desa, dokumen RKPDesa Setro sebagai dasar penyusunan APBDesa. Akuntanbilitas, RPJMDesa sebagai acuan dan arah perencanaan penyusunan RKPDesa, dokumen RKPDesa dasar penyusunan APBDesa. Partisipasi APBDesa Setro tahun 2017, musyawarah antara tim Penyusun APBDesa dengan BPD, LPMD sebagai perwakilan masyarakat. Transparansi APBDesa Setro, dibuat banner informasi di lokasi pelaksanaan program pembangunan. Akuntabilitas APBDesa Setro, penyusunan laporan pertanggungjawaban sebagai bentuk pertanggungjawaban penggunaan dana.
\end{abstract}

Kata Kunci: partisipasi; transparansi; akuntabilitas; dana desa; desa Setra 


\section{PENDAHULUAN}

Undang-undang No 6 Tahun 2014 menjelaskan bahwa desa pada tahun 2015 akan mendapatkan kucuran dana sebesar $10 \%$ dari APBN. Dana akan sampai ke desa tanpa melewati perantara. Jumlah yang diberikan ke setiap desa berbeda-beda tergantung geografis desa, jumlah penduduk dan angka kematian. Otonomi daerah adalah setiap hak, kewenangan dan kewajiban daerah untuk mengatur dan mengurus sendiri urusan dan kepentingan masyarakat setempat sesuai dengan kebijakan peraturan perundang-undangan (Muda, et al. 2018). UU Nomor 6 Tahun 2014 beserta peraturan pelaksanaanya telah mengamanatkan pemerintah desa untuk lebih mandiri dalam mengelola pemerintahan dan berbagai sumber daya alam yang dimiliki, termasuk di dalamnya pengelolaan keuangan dan kekayaan milik desa. Dalam APBN-P 2015 telah dialokasikan Dana Desa sebesar \pm Rp 20,776 triliun kepada seluruh desa yang tersebar di Indonesia. Jumlah desa yang ada saat ini sesuai Permendagri 39 Tahun 2015 sebanyak 74.093 desa. Selain Dana Desa, sesuai UU Desa pasal 72, Desa memiliki Pendapatan Asli Desa dan Pendapatan Transfer berupa Alokasi Dana Desa; Bagian dari Hasil Pajak dan Retribusi Kabupaten/Kota; dan Bantuan Keuangan dari APBD Provinsi/ Kabupaten/Kota (Widodo 2015).

Desa mempunyai kesempatan lebih besar untuk mengurus tata pemerintahannya sendiri serta pemerataan pelaksanaan pembangunan diharapkan dapat meningkatkan kesejahteraan dan kualitas hidup masyarakat desa. Permasalahan seperti kesenjangan antar wilayah, kemiskinan, dan masalah sosial budaya lainnya dapat diminimalisir. Pemerintah daerah merupakan bagian dari pemerintah pusat, koordinasi secara horizontal akan dapat memecahkan permasalahan yang ada di daerah (Dutta and Fan 2012). Sampai tahun 2018, desa sudah menerima sumber pendanaan dari dana desa empat kali. Peran besar yang diterima oleh desa, tentunya disertai dengan tanggung jawab yang besar pula. Oleh karena itu pemerintah desa harus bisa menerapkan prinsip partisipasi, transparansi dan akuntabilitas dalam tata pemerintahannya, dimana semua tahapan dalam pengelolaan keuangan desa harus dapat dipertanggungjawabkan kepada masyarakat desa sesuai dengan ketentuan.

Pengelolaan keuangan desa adalah keseluruhan kegiatan yang meliputi perencanaan, penganggaran, penatausahaan, pelaporan, pertanggungjawaban dan pengawasan keuangan desa (Keuangan dan Pembangunan, 2015). Keuangan Desa menurut UU Desa adalah semua hak dan kewajiban desa yang dapat dinilai dengan uang serta segala sesuatu berupa uang dan barang yang berhubungan dengan pelaksanaan hak dan kewajiban Desa. Hak dan kewajiban tersebut menimbulkan pendapatan, belanja, pembiayaan yang perlu diatur dalam pengelolaan keuangan desa yang baik. Siklus pengelolaan keuangan desa meliputi perencanaan, pelaksanaan, penatausahaan, pelaporan, dan pertanggungjawaban, dengan periodisasi 1 (satu) tahun anggaran, terhitung mulai tanggal 1 Januari sampai dengan 31 Desember (Keuangan dan Pembangunan 2015).

Dalam tahap perencanaan dan penganggaran, pemerintah desa harus melibatkan masyarakat desa yang direpresentasikan oleh Badan Permusyawaratan Desa (BPD), sehingga program kerja dan kegiatan yang disusun dapat mengakomodir kepentingan dan kebutuhan masyarakat desa serta sesuai dengan kemampuan yang dimiliki oleh desa tersebut. Perencanaan penganggaran yang dilakukan di desa sebenarnya bersifat desentralisasi yaitu desa diberi kewenangan untuk menyusun anggaran dari pendanaan yang ada untuk kepentingan masyarakat. Menurut (Dutta and Fan 2012), Sentralisasi dan desentralisasi berputar di sekitar masalah pembagian hak keputusan antara yang lebih tinggi dan yang lebih rendah

Selain itu pemerintah desa harus bisa menyelenggarakan pencatatan, atau minimal melakukan pembukuan atas transaksi keuangannya sebagai wujud pertanggungjawaban keuangan yang dilakukannya (Armaini 2017). Pemerintah desa menyusun perencanaan pembangunan desa sesuai dengan kewenangannya dengan mengacu pada perencanaan pembangunan kabupaten/ kota. Rencana pembangunan desa disusun untuk menjamin keterkaitan dan konsistensi antara perencanaan, penganggaran, pelaksanaan dan pengawasan. Dalam menyusun perencanaan pembangunan desa, pemerintah desa wajib menyelenggarakan musyawarah perencanaan pembangunan desa untuk menetapkan prioritas, program, kegiatan dan kebutuhan pembangunan desa yang didanai oleh APBDesa, swadaya masyarakat desa, dan atau APBD kabupaten/kota. Perencanaan pembanguunan desa menjadi pedoman bagi pemerintah desa dalam menyusun RPJMDesa, RKPDesa. Dalam menyususn RPJMDesa dan RKPDesa wajib menyelenggarakan musyawarah perencanaan pembangunan secara partisipatif. Partisipatif adalah mengikutsertakan masyarakat dan kelembagaan yang ada di desa. Musyawarah perencanaan pembangunan desa membahas dan menyepakati rancangan RPJMdesa. Hasil kesepakatan musyawarah dituangkan dalam berita acara. Kepala desa mengarahkan tim penyususn RPJMDesa melakukan perbaikan dokumen rancangan RPJMDesa berdasarkan hasil kesepakatan musyawarah perencanaan pembanguunan desa. Rancangan peraturan desa tentang RPJMDesa dibahas dan disepakati bersama oleh kepala desa dan BPD untuk ditetapkan menjadi peraturan desa tentang RPJMDesa.

Tahapan dalam perencanaan pembangunan desa dituangkan dalam bentuk penyusunan Rencana Pembangunan Jangka Menengah Desa (RPJMDesa) dan Rencana Kerja Pemerintah Desa (RKPDesa). Tahapan penganggaran yang dilakukan desa adalah penyusunan Anggaran Pendapatan dan Belanja Desa (APBDesa). RPJMDesa untuk jangka waktu 6 (enam) tahun. RPJMDesa memuat visi dan misi kepala desa, arah kebijakan pembangunan desa dan keuangan desa serta rencana kegiatan yang meliputi bidang penyelenggaran 
pemerintahan desa, pelaksanaan pembangunan desa, pembinaan kemasyarakatan desa dan pemberdayaan masyarakat desa. RKPDesa merupakan penjabaran dari RPJMDesa untuk jangka waktu 1 (satu) tahun memuat kerangka ekonomi desa dengan mempertimbangkan pendanaan yang akan diterima, program dan prioritas pembangunan desa. RKPDesa yang ditetapkan dengan peraturan desa menjadi bahan untuk penyusunan APBDesa. Peraturan desa tentang APBDesa ditetapkan paling lambat tanggal 31 desember tahun anggaran berjalan. Peraturan desa tentang APBDesa merupakan salah satu persyaratan pencairan dana desa tahun 2018.

Dalam tahapan perencanaan dan penganggaran perlu adanya partisipasi, transparansi dan akuntabilitas, agar pembangunan yang direncanakan sesuai dengan kebutuhan masyarakat dan keadaan setempat, memelihara dan mengembangkan hasil-hasil pembangunan desa. Partisipasi adalah keikutsertaan dan keterlibatan masyarakat secara aktif dalam proses pembangunan. Pemerintah desa harus melibatkan masyarakat desa baik dalam rencana program yang disululkan dalam RPJMDesa dan RKPDesa, sehingga program kerja dan kegiatan yang disusun dapat mengakomodir kepentingan dan kebutuhan masyarakat desa serta sesuai dengan kemampuan yang dimiliki oleh desa tersebut. Transparansi adalah setiap proses tahapan perencanaan pembangunan dapat dilihat dan diketahui secara langsung oleh seluruh masyarakat. Transparansi bisa di lihat saat adanya musyawarah dalam penyusunan rencana program/ kegiatan yang akan diusulkan baik di RPJMDesa dan RKPDesa.

Transparansi dalam menjalankan pemerintahan, pemerintah mengungapkan hal-hal yang sifatnya material secara berkala kepada pihak-pihak yang memiliki kepentingan, dalam hal ini yaitu masyarakat luas sehingga prinsip keterbukaan yang memungkinkan masyarakat untuk mengetahui dan mendapatkan akses informasi seluas-luasnya tentang keuangan daerah. Menurut krina, 2003 dalam (Hanifah and Praptoyo 2015) mengatakan prinsip-prinsip transparansi dapat diukur melalui sejumlah indikator seperti berikut : (1) Mekanisme yang menjamin sistem keterbukaan dan standarisasi dari semua proses-proses pelayanan publik; (2) Mekanisme yang memfasilitasi pertanyaanpertanyaan publik tentang berbagaikebijakan dan pelayanan publik, maupun proses-proses didalam sektor publik; (3) Mekanisme yang memfasilitasi pelaporan maupun penyebaran informasi maupun penyimpangan tindakan aparat publik didalam kegiatan melayani.

Transparansi anggaran dapat diukur melalui beberapa aspek, selain kemudahan akses pada informasi, mekanisme dan akses masyarakat dalam penyampaian pendapat juga harus diperhatikan. Keterbukaan (openness) mengacu kepada terbukanya kesempatan bagi rakyat untuk mengajukan tanggapan dan kritik terhadap pemerintah yang dinilainya tidak transparan (Widodo,2001:28) dalam (Sa'adah 2015).
Sehingga perlu adanya transparansi dalam penyusunan RPJMDesa, RKPDesa dan APBDesa, agar masyarakat bisa terlibat langsung dan memonitoring perencanaan pembangunan.

Akuntabilitas dapat dimaknai sebagai kewajiban untuk menyampaikan pertanggungjawaban untuk menjawab, menerangkan kinerja, dan tindakan seorang/ badan hukum/pimpinan kolektif atau organisasi kepada pihak yang memiliki hak atau berkewenangan untuk meminta keterangan dan pertanggungjawaban (Bastian, 2002:385) dalam (Hamid 2016). Pelaksanaan akuntabilitas dilingkungan instansi pemerintah, perlu diperhatikan prinsip-prinsip sebagai berikut (Hanifah and Praptoyo 2015): a). Harus ada komitmen dari pimpinan dan seluruh staf instansi untuk melakukan pengelolaan pelaksanaan misi agar akuntabel. b). Harus merupakan suatu sistem yang dapat menjamin penggunaan sumber- sumber daya secara konsisten dengan peraturan perundang-undangan yang berlaku. c). Harus dapat menunjukkan tingkat pencapaian tujuan dan sasaran yang telah ditetapkan. d). Harus berorientasi pada pencapaian visi dan misi serta hasil dan manfaat yang diperoleh. e). Harus jujur, objektif, transparan dan inovatif sebagai katalisator perubahan manajemen instansi pemerintah dalam bentuk pemutakhiran metode dan teknik pengukuran kinerja dan penyusunan laporan akuntabilitas (LAN \& BPKP, 2000 dalam Hanifah dan Praptoyo, 2015).

Transparansi anggaran mengacu pada sejauh mana publik dapat memperoleh informasi atas aktivitas keuangan pemerintah dan implikasinya secara komprohensif, akurat, dan tepat waktu (Andrianto, 2007: 21) dalam (Sa'adah 2015). Prinsip-prinsip akuntabilitas perlu di terapkan dalam penyusunan RPJMDesa dan RKPDesa sebagai output proses perencanaan pembangunan di desa, sehingga apa yang sudah direncanakan dapat dipertanggungjawabkan kepada pemerintahanan di atas desa dan masyarakat.

Akuntabilitas dalam penyelenggaraan pemerintahan daerah diartikan sebagai kewajiban pemerintah daerah untuk mempertanggungjawabkan pengelolaan dan pelaksanaan pemerintahan di daerah dalam rangka otonomi daerah untuk mencapai tujuan yang telah ditetapkan melalui media pertanggungjawaban yang terukur baik dari segi kualitasnya maupun kuantitasnya (Hanifah and Praptoyo 2015). Pemerintah daerah sebagai pelaku pemerintahan harus bertanggungjawab terhadap apa yang telah dilakukannya terhadap masyarakat dalam rangka menjalankan tugas, wewenang, dan kewajiban Pemerintah Daerah (Sabarno, 2007:129).

Dalam akuntabilitas terkandung kewajiban untuk menyajikan dan melaporkan segala kegiatan, terutama dalam bidang administrasi keuangan kepada pihak yang lebih tinggi. Media pertanggungjawaban akuntabilitas tidak terbatas pada laporan pertanggungjawaban, akan tetapi juga mencakup aspek-aspek kemudahan pemberi mandat untuk mendapatkan informasi, baik langsung 
maupun tidak langsung secara lisan maupun tulisan, sehingga akuntabilitas dapat tumbuh pada lingkungan yang mengutamakan keterbukaan sebagai landasan pertanggungjawaban (Sulistiyani, 2011:71).

Akuntabilitas adalah setiap proses dan tahapan-tahapan kegiatan pembangunan dapat dipertanggungjawabkan dengan benar, baik pada pemerintah di desa maupun pada masyarakat. Akuntabilitas dapat tercipta jika program-program apa yang direncanakan dapat dipertanggungjawabkan dan sesuai dengan kebutuhan masyarakat desa saat itu, tidak menyalahi aturan dari pemerintah di atasnya Desa.

Namun demikian, peran dan tanggung jawab yang diterima oleh desa belum diimbangi dengan sumber daya manusia (SDM) yang memadai baik dari segi kuantitas maupun kualitas, hal ini seperti hasil penelitian yang dilakukan (Liando, Lambey, and Wokas 2017). Kendala umum lainnya yaitu desa belum memiliki prosedur serta dukungan sarana dan prasarana dalam pengelolaan keuangannya serta belum kritisnya masyarakat atas pengelolaan anggaran pendapatan dan belanja desa. Besarnya dana yang harus dikelola oleh pemerintah desa memiliki risiko yang cukup tinggi dalam pengelolaannya, khususnya bagi aparatur pemerintah desa. Mengutip pernyataan Kepala Bagian Pemerintahan Desa Kabupaten Jember, Winardi yang dimuat dalam situs surabaya.bisnis.com Minggu, 30/11/2014 18:23 WIB, dua kepala desa tersebut yaitu desa Paseban kecamatan Kencong, dan Desa Pecoro Kecamatan Rambipuji (Sri et al. 2017). Fenomena pejabat daerah yang tersangkut kasus hukum jangan sampai terulang kembali dalam skala pemerintahan desa. Aparatur pemerintah desa dan masyarakat desa yang direpresentasikan oleh BPD harus memiliki pemahaman atas peraturan perundang-undangan dan ketentuan lainnya, serta memiliki kemampuan untuk melaksanakan pencatatan, pelaporan dan pertanggungjawaban.

Berdasarkan latar belakang masalah tersebut, peneliti ingin mengetahui bagaimana pelaksanaan partisipasi, transparansi, akuntanbilitas dalam perencanaan pembangunan desa (RPJMDesa dan RKPDesa) dan penganggaran dana desa (APBDesa) desa Setro Kecamatan Menganti Kabupaten Gresik Jawa Timur.

Merujuk pada rumusan masalah yang telah dikemukakan sebelumnya tujuan penelitian ini adalah untuk mengetahui ;1) partisipasi, transparansi, akuntabilitas dalam penyusunan RPJMDesa dan RKPDesa, 2) partisipasi, transparansi, akuntabilitas dalam penyusunan APBDesa.

\section{METODE}

Penelitian ini menggunakan tipe penelitian kualitatif, untuk mengetahui bagaimana pelaksanaan partisipasi, transparansi dan akuntabilitas dalam perencanaan pembangunan (penyusunan RPJMDesa dan RKPDesa) dan tahap penganggaran (penyusunan APBdesa) tahun anggaran 2017 di desa Setro kecamatan Menganti Kabupaten Gresik Jawa Timur. Teknik pengumpulan data dengan observasi langsung pelaksanaan musyawarah penyusunan RKPDesa dan APBDesa Setro tahun anggara 2017, wawancara dan dokumentasi terkait penyusunan RPJMDesa. Informan penelitian ini adalah perangkat desa, BPD dan perwakilan masyarakat di desa Setro. Teknik analisis data dilakukan dengan tahap yang dikemukakan Miles and Huberman (1984) dalam Sugiyono (2013: 91) yakni langkah data reduction, data display, dan verification.

\section{HASIL}

Penelitian ini dilakukan di Desa Setro, terletak di wilayah kecamatan Menganti Kabupaten Gresik Propinsi Jawa Timur, terdiri dua dusun yaitu dusun Setro dan dusun Pengampon. Jumlah penduduk 5.993 jiwa dengan jenis kelamin laki-laki 3.017 jiwa dan perempuan 2.976 jiwa. Jumlah penduduk yang bekerja di desa setro terdiri 95 jiwa PNS, 7 jiwa TNI/Polri, 1.055 jiwa sebagai karyawan swasta, 467 sebagai Wiraswasta/ pedagang, 391 sebagai petani, 8 jiwa pensiunan PNS, 324 jiwa dengan profesi lain-lain ( Badan Pusat Statistik Kabupaten Gresik).

Desa Setro mempunyai visi Mewujudkan Masyarakat Bersatu Membangun Desa Kuat Keyakinan Beragama, Sejahtera, Aman dan Tentram Serta Melestarikan Kearifan Budaya Lokal. Untuk mewujudkan visi tersebut terdapat beberapa misi yang dilakukan desa Setro: mewujudkan masyarakat yang beriman, bertaqwa dan berakhlaqul karimah, meningkatkan peran serta dan pemberdayaan masyarakat, mewujudkan pemerintah yang baik dan berwibawa, mewujudkan kondisi yang aman, tertib, tentram dan damai, mewujudkan kondisi desa yang bebas dari polusi sampah, meningkatkan pembangunan ekonomi desa dengan titik berat ekonomi kerakyatan.

\section{PEMBAHASAN}

Rencana Pembangunan Jangka Menengah Desa (RPJMDesa) Setro disusun periode 2013 - 2019. Sebagai pedoman program kerja untuk masa enam tahun RPJMDesa merupakan turunan dari sebuah cita-cita yang ingin dicapai dimasa depan segenap warga masyarakat desa Setro. RPJMDesa memuat visi dan misi kepala desa dan apa yang akan dilakukan selama memimpin desanya serta arah kebijakan pembangunan desa, rencana kegiatan yang meliputi penyelenggaran pemerintahan desa, pelaksanaan pembangunan desa, pembinaan kemasyarakatan desa dan pemberdayaan masyarakat. Untuk menyelaraskan dengan perkembangan kondisi dan kebutuhan masyarakat dengan arah kebijakan kabupaten/ kota maka pada Tahun 2015 desa Setro melakukan revisi atas RPJMDesa. 
Dari hasil wawancara dengan perangkat desa Setro, LPMD diperoleh informasi: Sebelum penyusunan RPJMDesa Setro di dahului dengan musyawarah perencanaan pembangunan desa yang dihadiri oleh kepala desa, unsur perangkat desa, BPD, wakil-wakil kelompok masyarakat. Musrebangdes (Musyawarah Perencanaan Pembangunan Desa) dilakukan Jumat, 30 Oktober 2015, jam 19.00 WIB di Balai Desa Setro yang dihadiri sebanyak 57 orang. Materi yang dibahas dalam musrebangdes desa Setro meliputi pengkajian keadaan desa, rencana program pembangunan Kabupaten/ Kota yang akan masuk ke desa, Rencana program pembangunan kawasan perdesaaan, usulan rencana kegiatan pembangunan desa dari dusun atau kelompok masyarakat. Hasil musrebangdes menyepakai bahwa seluruh materi yang dibahas dijadikan bahan untuk Rancangan RPJMDesa yang akan diajukan dalam Musyawarah Desa (Musdes) RPJMDesa. Bentuk Partisipasi masyarakat dalam perencanaan pembangunan di desa Setro dilakukan dengan melibatkan seluruh lembaga yang ada di desa Setro baik tingkat RT, RW dan kepala dusun serta tokoh agama yang ada di desa Setro dalam Musrebangdes dan Musyawarah Desa (Musdes) untuk penyusunan RPJMDesa dari bahan rancangan RPJMDesa.

Tingkat partisipasi masyarakat dalam pelaksanaan musyawarah desa dapat dilihat dari tingkat kehadiran dan jumlah usulan oleh masyarakat (Sulumin 2015). Musrebangdes di hadiri 57, sehingga pelaksanaan partisipasi dalam perencanaan pembangunan di desa Setro telah dilaksanakan dengan baik. Partisipasi masyarakat dalam penentuan kebijakan publik menjadi kekuatan pendorong untuk mempercepat terpenuhinya prinsip akuntabilitas dari penyelenggaraan pemerintahan di desa. Partisipasi public menyiratkan keterlibatan oleh warga negara, bisnis, organisasi non pemerintah dan sector social lainnya dalam kekuasaan kelembagaaan politik. Keterlibatan ini bertujuan untuk berkonsultasi, mengelola atau memberikan umpan balik (RuvalcabaGomez 2019)

Penganggaran partisipasi masyarakat sangat penting untuk mencegah kebijakan-kebijakan yang menyimpang. Prinsip dan indikator partisipasi masyarakat dalam pengganggaran menurut Sulistioni dan Hendriadi, 2004 dalam Taufik (2013) dalam (Astuti and Yulianto 2016) mencakup hal-hal berikut: a) adanya akses bagi partisipasi aktif publik dalam proses perumusan program dan pengambilan keputusan anggaran; b) adanya peraturan yang memberikan tempat ruang kontrol oleh lembaga independen dan masyarakat baik secara perorangan maupun kelembagaan sebagai media check and balances ; c) adanya sikap proaktif pemerintah daerah untuk mendorong partisipasi warga pada proses penganggaran. Hal ini mengingat kesenjangan yang tajam antara kesadaran masyarakat tentang cara berpartisipasi yang efektif dan cita-cita mewujudkan APBD yang aspiratif.
Selanjutnya kepala desa akan menyusun Tim Penyusunan RPJMDesa dan RKPDesa yang terdiri 11 orang yang terdiri dari perangkat desa, LPMD desa Setro dengan menyertakan perempuan didalamnya. Tim ini akan melakukan Musdes (Musyawarah Desa) untuk menyusun RPJMDesa dari hasil usulan yang telah disepakati dalam Musrebangdes. Transparansi yang dilakukan dalam perencanaan pembangunan di desa setro, dilakukannya mekanisme dan akses masyarakat dalam penyampaian pendapat, keterbukaan (openness) mengacu kepada terbukanya kesempatan bagi rakyat untuk mengajukan tanggapan dan kritik terhadap pemerintahan desa, hal ini sesuai dengan penelitian yang dilakukan (Kumalasari and Riharjo 2016). Dari hasil penelitian yang dilakukan oleh Pina, Torres, and Royo 2007;

Cuillier and Piotrowski 2009; Pina, Torres, and Royo 2010; Rodr' 'guez Bol'1var, del Carmen Caba P' erez, and L' opez-Hern' andez 2015; Bearfield and Bowman 2017 dalam (Krah and Mertens 2020), menyatakan bahwa penggunaan internet untuk memberikan informasi ke masyarakat telah terbutki meningkatkan transparansi karena internet membuat lebih mudah dan nyaman bagi warga unntuk mencari data dan mengakses informasi resmi dan melakukan transaksi. Transparansi sebagai open government sangat terkait dengan hal akses informasi dan akuntabilitas (Criado, RuvalcabaGómez, and Valenzuela-Mendoza 2018). Pelaksanaan transparansi di desa Setro belum menggunakan internet tetapi desa Setro telah menginformasikan perencanaan anggaran berupa RKD Desa dalam bentuk banner yang diletakkan di kantor Desa. Prinsip-prinsip transparansi dapat diukur melalui sejumlah indikator seperti berikut: 1) Mekanisme yang menjamin sistem keterbukaan dan standarisasi dari semua proses pelayanan publik; 2) Mekanisme yang memfasilitasi pertanyaan-pertanyaan publik tentang berbagai kebijakan dan pelayanan publik, maupun proses-proses didalam sektor publik; 3) Mekanisme yang memfasilitasi pelaporan maupun penyebaran informasi maupun penyimpangan tindakan aparat publik didalam kegiatan melayani (Bappenas 2003) dalam (Astuti and Yulianto 2016)

RPJMDesa yang telah disusun, disahkan oleh Kepala Desa dalam bentuk Peraturan Desa. RPJMDesa digunakan desa sebagai dasar penyusunan Rencana Kerja Pemerintahan Desa (RKPDesa) yang disusun setiap tahun dengan mengacu pada RPJMDesa. Bentuk akuntanbilitas dalam perencanaan pembangunan adalah desa sebagai pelaku pemerintahan bertanggungjawab terhadap apa yang telah dilakukannya terhadap masyarakat dalam rangka menjalankan tugas, wewenang, dan kewajiban dalam perencanaan pembangunan dengan melaksanakan tahapan-tahapan dalam penyusunan RPJMDesa serta menggunakan RPJMDesa sebagai acuan dan arah perencanaan tahunan yang akan dijabarkan dalam bentuk RKPDesa setiap tahun. Untuk mewujudkan kesejahteraan dan 
kemakmuran masyarakat diperlukan peran semua pihak baik masyarakat desa, perangkat desa dan organisasiorganisasi yang ada di desa. Sejumlah alternatif strategi dalam peningkatan efektivitas dan efisiensi pembangunan di perdesaan sebagai berikut (Bachrein, 2010) dalam (Cristian 2015) optimalisasi kegiatan Musrenbang dengan melibatkan seluruh pemangku kepentingan mulai dari tingkat desa, kecamatan, sampai kabupaten/provinsi dengan memperhatikan pada dokumen perencanaan kabupaten dan provinsi (UU No. 25 Tahun 2004 tentang Sistem Perencanaan Pembangunan Nasional), (2) integrasi dan keterpaduan dalam bentuk pendekatan kewilayahan dengan menempatkan desa sebagai strata wilayah/pemerintahan terendah, (3) memanfaatkan dan memberdayakan keberadaan kelembagaan lokal/ perdesaan yang telah ada, (4) melakukan sosialisasi dan melibatkan peran perangkat desa dan masyarakat untuk setiap program/ kegiatan yang dilaksanakan, (5) investasi pemerintah untuk perbaikan infrastruktur perdesaan, dan (6) optimalisasi peran perangkat desa dan tokoh masyarakat dalam pembangunan, mulai perencanaan, pelaksanaan, sampai evaluasi, dan monitoring. Menurut Carothers \& Brechenmacher, 2014 dalam (García 2019) menyatakan bahwa there is broad agreement that transparency and accountability are pivotal to any good governance reform. International aid providers have increasingly prioritized accountability, transparency, participation, and inclusion as a political approach to development. Hal tersebut menegaskan bahwa kesepakatan antara transparansi dan akuntabilitas sangat penting dalam perubahan tata kelola yang lebih baik.

Rencana Kinerja Pemerintah Desa (RKPDesa) merupakan dokumen perencanaan pembangunan desa sebagai bentuk penjabaran RPJMDesa yang memuat rancangan kerangka ekonomi desa dengan mempertimbangkan kerangka pendanaan yang akan diperoleh desa, program proritas pembangunan desa, rencana kerja dan pendanaan dengan mendorong partisipasi masyarakat dengan mengacu kepada RPJMDesa.

Sesuai dengan Peraturan Menteri Dalam Negeri Nomor 114 Tahun 2014 tentang pedoman pembangunan Desa, bahwa penyusunan RKP Desa harus dilakukan sesuai dengan tahapan yang meliputi ; (1) Penyusunan perencanaan pembangunan Desa melalui musyawarah Desa, (2) Pembentukan tim penyusun RKP Desa, (3) Pencermatan pagu indikatif Desa dan penyelarasan program/kegiatan masuk ke Desa, (4) Pencermatan ulang dokumen RPJM Desa, (5) Penyusunan rancangan RKP Desa, (6) Penyusunan RKP Desa melalui musyawarah perencanaan pembangunan Desa, (7) Penetapan RKP Desa, (8) Perubahan RKP Desa, dan (9) Pengajuan daftar usulan RKP Desa.

Bentuk partisipasi perencaan RKPDesa Setro dilakukan pada aktifitas 1 dan 6. Aktivitas 1 di desa Setro dilakukan dengan menggali usulan dari setiap RT,
RW, Kepala Dusun secara berjenjang untuk rencana program pembangunan yang diusulkan ke Desa. Usulan dari jenjang lembaga pemerintah dibawah ini penting untuk mengetahui dan merespon kondisi yang ada di masyarakat serta apa yang dibutuhkan masyarakat. Partisipasi masyarakat mengacu pada peran pemerintah dalam mengajak warga untuk berpartisipasi dalam musyawarah dan berkontribusi dalam pengembangan pemerintahan yang lebih responsive, akuntabel, inovatif dan efektif. Ini menyiratkan bahwa pemerintah tidak hanya menyediakan ruang untuk menyuarakan pendapat, tetapi juga mendorong mendorong, menjamin dan mencari kontribusi masyarakat untuk pembuatan kebijakan public (Calderón-Orellana and ArayaBugueño 2019).

Perencanaan adalah suatu proses untuk menentukan tindakan masa depan yang tepat, melalui urutan pilihan, dengan memperhitungkan sumber daya yang tersedia. Perencanaan pembangunan yang baik akan memberikan dampak yang baik pula terhadap pembangunan suatu daerah. Hal itu juga harus didukung dengan sumber daya manusia yang kompeten atau mumpuni agar perencanaan pembangunan yang baik dapat terwujud. Di samping itu juga yang menjadi sangat penting dalam perencanaan pembangunan yaitu harus ada sebuah aturan yang jelas agar bisa dijadikan sebagai pedoman atau acuan bagi pemerintah sebagai pelaku pembuat kebijakan. Selain sebagai pedoman atau acuan, dengan aturan yang jelas akan dapat mewujudkan tata kelolah pemerintah yang baik dalam perencanaan pembangunan.

Bentuk partisipasi dari aktivita no 6 adalah Pelaksanaan Musrenbang Desa. Musrebang desa Setro untuk penyusunan RKPDesa tahun 2017 dilaksanakan tanggal 14 Nopember 2016, yang dihadiri 51 peserta yang terdiri perangkat desa, BPD, LPMD, Kasun, Ketua RT, Ketua RW, organisasi kemasyarakatan. Materi yang dibahas dalam musrebang desa Setro adalah pencermatan RPJMDesa, Evaluasi RKPDesa tahun berjalan, Penetapan kegiatan-kegiatan yang ada di desa, pembentukan tim pelaksana kegiatan. Hasil musrebang desa Setro adalah menyepakati kegiatan-kegiatan pembangunan desa tahun 2017, memprioritaskan kegiatan-kegiatan yang belum terlaksana untuk dilaksanakan di tahun 2017, menyepakati panitia pelaksana.

Musrenbangdes adalah forum musyawarah tahunan pihak yang berkepentingan untuk mengatasi permasalahan desa dan pihak yang akan terkena dampak hasil musyawarah untuk menyepakati rencana kegiatan tahun anggaran berikutnya (tahun yang direncanakan). Musrenbangdes menginginkan adanya kebersamaan antara Pemerintah Desa dan masyarakat dalam memilih mana yang terbaik untuk pembangunan Desa kedepanya. Musrenbang dilakukan di daerah dan sebagai mekanisme untuk mempertemukan usulan/ kebutuhan masyarakat (bottom-up planning) dengan apa yang akan diprogram pemerintah (top-down planning). 
Musyawarah Perencanaan Pembangunan (Musrenbang), identik dengan sebuah proses pembangunan yang lebih menegdepankan partisipatif, demokratis dan transparan. Dengan begitu dapat dikatakan bahwa Musrenbang dapat mengakomodasi kepentingan pembangunan bagi masyarakat. Musyawarah Perencanaan Pembangunan Desa atau yang disebut dengan nama lain adalah musyawarah antara Badan Permusyawaratan Desa, Pemerintah Desa, dan unsur masyarakat yang diselenggarakan oleh Pemerintah Desa untuk menetapkan prioritas, program, kegiatan, dan kebutuhan Pembangunan Desa yang didanai oleh Anggaran Pendapatan dan Belanja Desa, swadaya masyarakat Desa, dan/atau Anggaran Pendapatan dan Belanja Daerah Kabupaten/Kota.

Dengan Undang-Undang Nomor 25 Tahun 2004 ini perencanaan pembangunan bersifat bottom up yang menekankan partisipasi dari banyak pihak. Sehingga pembangunan dapat dirasakan oleh banyak pihak seperti masyarakat, sektor swasta, dan pemerintah. Perencanaan pembangunan yang bersifat bottom up dengan lebih mengedepankan partisipatif dan komunikatif secara aktif dari banyak pihak merupakan prinsip utama dari Undang-Undang Nomor 25 Tahun 2004 tentang Sistem Perencanaan Pembangunan Nasional. Dalam mewujudkan pembangunan yang baik secara nasional, perencanaan pembangunan harus mulai disusun dari tingkat yang paling bawah yaitu Desa yang tujuannya untuk memberikan kontribusi positif terhadap pembangunan nasional. Oleh karena itu, Desa memegang peranan penting dalam pembangunan nasional bukan hanya dikarenakan sebagian besar rakyat Indonesia bertempat tinggal di desa, tetapi desa memberikan kontribusi besar dalam menciptakan stabilitas pembangunan nasional. Pembangunan Desa merupakan bagian dari rangkaian pembangunan nasional.

Desa seringkali identik dengan dua hal yakni sebagai objek dan subjek dalam pembangunan. Dikatakan sebagai objek pembangunan, karena sebagaian penduduk di pedesaan dilihat dari aspek kualitas masih perlu dilakukan pemberdayaan. Sebaliknya sebagai subjek pembangunan penduduk pedesaan memegang peranan yang sangat penting sebagai kekuatan penentu (pelaku) dalam proses pembangunan pedesaan maupun pembangunan nasional.

Pembangunan yang direncanakan dengan menggali informasi program-program dari masyarakat akan menumbuhkan rasa kepedulian baik dalam proses perencanaan dan pelaksanaan pembangunan. Bentuk Akuntabilitas dalam penganggaran adalah dokumen RKPDesa digunakan sebagai dasar penyusunan Anggaran Pendapatan Dan Belanja Desa (APBDesa) dengan menyesuikan besarnya pendapatan atau pendanaan yang akan diperoleh desa. Pendanaan bisa bersumber dari a. Pendapatan Asli Desa yang diperoleh dari tanah kas desa/ bengkok, hasil usaha desa, penggalangan swadaya masyarakat tingkat dsa dan dusun, gotong royong, dan atau pendapatan lainlain yang sah ; b. Dana desa; c. Alokasi dana desa; d. Bagi hasil pajak dan retribusi daerah. Pelaksanaan akuntabilitas dalam prosese penganggaran adalah penyusunan Surat Keputusan Kepala Desa tentang RKPDesa dan APBDesa, hal ini mempunyai kekuatan hukum dan sebagai dasar dan acuan pelaksanaan program pembangunan di masyrakat desa.

Penyusunan dokumen Rencana Kerja Pembangunan Desa (RKP-Desa) ini mempunyai tujuan: a. Agar desa memiliki dokumen perencanaan pembangunan tahunan yang berkekuatan hukum tetap; b. Sebagai dasar/ pedoman kegiatan atau pelaksanaan pembangunan di desa; c. Sebagai dasar penyusunan Peraturan Desa tentang Anggaran Pendapatan dan Belanja Desa (APBDesa). Menurut (Cristian 2015), manfaat RKPDesa a. Lebih menjamin kesinambungan pembangunan ditingkat desa; b. Sebagai pedoman dan acuan pembangunan desa; c. Pemberi arah kegiatan tahunan di desa; d. Menampung aspirasi yang sesuai kebutuhan masyarakat dan dipadukan dengan program pembangunan supra desa; e. Dapat mendorong partisipasi dan swadaya dari masyarakat.

Transparansi dalam RKPDesa Setro adalah keterbukaan dokumen RKPDesa yang telah disusun sebagai dasar dalam penyusunan APBDesa. Hal ini sesuai Nordiawan (2006) dalam (Anwar and Jatmiko 2012) menyatakan Transparansi memberikan informasi keuangan yang terbuka dan jujur kepada masyarakat berdasarkan pertimbangan bahwa masyarakat memiliki hak untuk mengetahui secara terbuka dan menyeluruh atas pertanggungjawaban pemerintah dalam pengelolaan sumber daya yang dipercayakan kepadanya dan ketaatannya pada peraturan perundang- undangan.

Anggaran Pendapatan Belanja Desa (APBDesa) Setro tahun 2017 sebagai dasar anggaran pelaksanaan pembangunan tahun 2018 di desa Setro. Dalam penyusunan APBDesa menselaraskan antara program pembangunan dalam RKPDesa tahun 2017 dan rencana pendanaan yang akan diterima desa Setro tahun 2018. APBDesa berisi Pendapatan Asli Desa ( Hasil usaha, hasil aset, swadaya, partisipasi, gotong royong dan lailain pendapatan asli desa), Transfer (Dana desa, Bagi Hasil Pajak dan Retribusi Daerah, Alokasi Dana Desa, Bantuan keuangan APBd Propinsi, bantusn Keuangan APB Kabupaten), Lain-lain (Hibah dan sumbangan dari pihak ketiga yang mengikat, lain-lain pendapatan desa yang sah); Belanja desa dipergunakan dalam rangka mendanai penyelenggaran-penyelenggaraan pemerintahan desa, pelaksanaan pembangunan desa, pembinaan kemasyarakatan desa, pemberdayaan masyarakat desa dan belanja tak terduga).

Bentuk partisipasi yang terjadi dalam penganggan di APBDesa setro adalah adanya musyawarah antara tim Penyusun APBDesa dengan BPD, LPMD sebaggai perwakilan masyarakat. Badan Permusyawaratan Desa adalah lembaga yang melaksanakan fungsi pemerintahan yang anggotanya merupakan wakil dari 
penduduk Desa berdasarkan keterwakilan wilayah dan ditetapkan secara demokratis (Hanifah and Praptoyo 2015). Musyawarah tersebut akan membahas kesesuaian antara rencana pendanaan yang akan diterima desa setro dengan beberapa program yang telah ada di RKPDesa Setro tahun 2017. Transparansi dalam APBDesa adalah dibuat banner informasi tentang APBDesa desa Setro tahun 2017. Dengan adanya banner masyarakat mudah untuk memperoleh informasi besarnya pendanaan dan belanja yang akan terjadi, selain itu masyarakat dapat sebagai control dan monotoring besarnya dana dalam suatu program dengan realisasi program pembangunan yang terjadi di lapangan/ desa Setro. Bentuk transparansi yang terjadi di desa Setro adalah pada setiap tempat dilakukannya program pembangunan terdapat papan informasi tentang pembangunan apa, berapa besarnya dana, waktu penyelesaian pembangunan. Menurut (Faraon 2018), adanya transparansi melalui open source, siapapun dengan kompetensi yang memadai dapat mengakses, meningkatkandan menggunakan teknologi untuk memnuhi kebutuhan informasi.

Akuntanbilitas APBDesa dilakukan dengan pembuatan laporan pertanggungjawaban oleh tim pelaksana, sebagai bentuk pertanggungjawaban penggunaan dana yang diperoleh. Dana yang diperoleh desa tiap termen dari beberapa sumber digunakan untuk pelaksanaan pembangunan sesuai dalam APBDesa, dan dipertanggungjawabkan penggunaan dana tersebut dalam bentuk laporan. Tata kelola pemerintahan yang baik merupakan salah satu tuntunan masyarakat yang harus dipenuhi. Salah satu pilar tata kelola tersebut adalah akuntabilitas. Sabeni dan Ghozali (2001) dalam (Anwar and Jatmiko 2012), menyatakan Akuntabilitas atau pertanggungjawaban (accountability) merupakan suatu bentuk keharusan seseorang (pimpinan/pejabat/ pelaksana) untuk menjamin bahwa tugas dan kewajiban yang diembannya sudah dilaksanakan sesuai ketentuan yang berlaku. Akuntabilitas dapa dilihat melalui laporan tertulis yang informatif dan transparan. Mardiasmo (2002) mengatakan Akuntabilitas publik adalah kewajiban pihak pemegang amanah untuk memberikan pertanggungjawaban, menyajikan dan mengungkapkan segala aktivitasnya dan kegiatan yang menjadi tanggungjawabnya kepada pihak pemberi amanah (Principal) yang memiliki hak dan kewenangan untuk meminta pertanggungjawaban. Menurut Nordiawan (2006) mengatakan Akuntabilitas adalah mempertanggungjawabkan pengelolaan sumber daya serta pelaksanaan kebijakan yang dipercayakan kepada entitas pelaporan dalam mencapai tujuan yang telah ditetapkan secara periodik. Seperti yang telah dijabarkan, dari beberapa definisi tersebut menurut Mardiasmo (2002) menjelaskan terdapat lima dimensi akuntabilitas yang harus dipenuhi oleh organisasi sektor publik, yaitu: (1) Akuntabilitas Keuangan, Akuntabilitas keuangan terkait dengan penghindaran penyalahgunaan dana publik; (2) Akuntabilitas Kejujuran dan Akuntabilitas Hukum, akuntabilitas kejujuran terkait de- ngan penghindaran penyalahgunaan jabatan, sedangkan akuntabilitas hukum terkait de- ngan jaminan dengan adanya kepatuhan terhadap hukum dan peraturan lain yang diisyaratkan dalam penggunaan sumber dana publik; (3) Akuntabilitas Proses, akuntabi- litas proses terkait dengan apakah prosedur yang digunakan dalam melaksanakan tugas sudah cukup baik dalam hal kecukupan sis- tem informasi akuntansi, sistem informasi manajemen dan prosedur administrasi; (4) Akuntabilitas Program, akuntabilitas pro- gram terkait dengan pertimbangan apakah tujuan dapat ditetapkan dapat dicapai atau tidak, dan apakah telah mempertimbangkan alternative program yang memberikan hasil yang optimal dengan biaya yang minimal; (5) Akuntabilitas Kebijakan, akuntabilitas kebijakan terkait dengan pertanggungjawaban Pemerintah, baik Pusat maupun daerah atas kebijakankebijakan yang diambil pemerintah terhadap DPR/DPRD dan masyarakat luas.

Pelaksanaan akuntabilitas di desa Setro dapat terlihat dari penyusunan pertanggungjawaban penggunaan dan yang telah diterima di desa. Laporan pertanggung jawaban di lakukan secara manual pencatatannya, tapi saat ini sudah dilakukan secara komputerisasi dengan menggunakan software untuk menyusun laporan pertanggungjawaban, hal ini terjadi karean pengaruh modernisasi teknologi. Open Government $(O G)$ dilihat sebagai modernisasi negara, tercermin dalam komitmen yang berusaha untuk mengubah dan memodernisasi administrasi. Baik dalam ruang lingkup internal, atau hubungan negara dengan masyarakat yang menghasilkan kolaborasi yang lebih besar dengan pemerintah, lembaga dengan mempertimbangkan kebutuhan dan tututan lingkungan (Volta 2019). Akuntabilitas dari bawak ke atas efekitif karena pemerintah pusat memiliki informasi langsung tentang hasil dari kebijakan loka, masyarakat memiliki insentif adanya koropsi, pembuat kebijakan peka terhadap hukuman social dari masyarakat (Freire, Galdino, and Mignozzetti 2020).

\section{KESIMPULAN}

Perencanaan pembangunan (RPJMDesa dan RKPDesa) desa Setro melibatkan perangkat desa, BPD, LPMD, tokoh masyarakat, organisasi kemasyarakatan, RT,RW, kepala dusun dalam musyawarahnya, mekanisme dan akses masyarakat dalam penyampaian pendapat, keterbukaan (openness) mengacu kepada terbukanya kesempatan bagi rakyat untuk mengajukan tanggapan dan kritik terhadap pemerintahan desa, keterbukaan dokumen RKPDesa yang telah disusun sebagai dasar dalam penyusunan APBDesa. Pelaksanaan Akuntanbilitas RPJMDesa, dokumen RPJMDesa sebagai acuan dan arah perencanaan tahunan yang akan dijabarkan dalam bentuk RKPDesa setiap tahun, dokumen RKPDesa digunakan sebagai dasar penyusunan Anggaran Pendapatan Dan Belanja Desa (APBDesa). 
Tahapan penganggaran penyusunan APBDesa tahun 2017, adanya partisipasi antara tim Penyusun APBDesa dengan BPD, LPMD sebaggai perwakilan masyarakat dalam musyawarah, dibuat banner informasi tentang APBDesa desa Setro tahun 2017 di setiap tempat dilakukannya program pembangunan terdapat papan informasi tentang pembangunan apa, berapa besarnya dana, waktu penyelesaian pembangunan, penyusuna laporan pertanggungjawaban oleh tim pelaksana, sebagai bentuk pertanggungjawaban penggunaan dana yang diperoleh.

\section{DAFTAR PUSTAKA}

Anwar, M. and Jatmiko, B., 2012. Kontribusi Dan Peran Pengelolaan Keuangan Desa Untuk Mewujudkan Anggaran Pendapatan Dan Belanja Desa Yang Transparan Dan Akuntabel (Survey Pada Perangkat Desa Di Kecamatan Ngaglik, Sleman, Yogyakarta). Jurnal Universitas Muhammadiyah Yogyakarta: 387-410.

Armaini, R., 2017. Asas-asas Pengelolaan Keuangan Desa dalam Pencapaian Akuntabilitas Penggunaan Dana Desa di desa Karang Agung Kabupaten Pali. Jurnal ACSY: Jurnal Accounting Politeknik Sekayu, 6(1), pp.57-67.

Astuti, T.P. and Yulianto, Y., 2016. Good Governance Pengelolaan Keuangan Desa Menyongsong Berlakunya Undang-Undang No. 6 Tahun 2014. Berkala Akuntansi dan Keuangan Indonesia, 1(1).

Calderón-Orellana, M. and Araya-Bugueño, R., 2019. The Codes of Ethics in Public Sector and the Incorporation of Values that Promote Open Government: The Chilean case. eJournal of eDemocracy \& Open Government, 11(2).

Criado, J.I., Ruvalcaba-Gómez, E.A. and ValenzuelaMendoza, R., 2018. Revisiting the Open Government Phenomenon. A Meta-Analysis of the International Literature. JeDEM - eJournal of eDemocracy and Open Government 10(1): 50-81.

Cristian, H., 2015. Studi tentang Pelaksanaan Rencana Kerja Pembangunan Desa (RKPDes) Tahun 2013 di Desa Loa Janan Ulu Kecamatan Loa Janan Kabupaten Kutai Kartanegara. Kutai: eJournal Pemerintahan Integratif, 3, pp.2337-8670.

Dutta, S. and Fan, Q., 2012. Incentives for innovation and centralized versus delegated capital budgeting. Journal of Accounting and Economics, 53(3), pp.592-611.

Faraon, M., 2018. Concept-driven design for democracy: advancing co-creative media to support citizen participation and democratic engagement. eJournal of eDemocracy \& Open Government, 10(1), pp.23-49.

Freire, D., Galdino, M. and Mignozzetti, U., 2020. Bottom-up accountability and public service provision: Evidence from a field experiment in Brazil. Research \& Politics, 7(2).
García, D.R., 2019. Politics, Technology, and Accountability: The Transparency Façade of Open Government Data Reforms in Paraguay. JeDEMeJournal of eDemocracy and Open Government, 11(2), pp.60-93.

Hamid, Alfian. 2016. Transparansi Dan Akuntabilitas Pengelolaan Keuangan Alokasi Dana Desa (ADD) Dalam Pencapaian Good Governance.

Hanifah, S.I. and Praptoyo, S., 2015. Akuntabilitas dan Transparansi Pertanggungjawaban Anggaran Pendapatan Belanja Desa (APBDes). Jurnal Ilmu \& Riset Akuntansi, 4(8), pp.1-15.

Keuangan, B.P. and Pembangunan, R.I., 2015. Petunjuk Pelaksanaan Bimbingan dan Konsultasi Pengelolaan Keuangan Desa. Jakarta: Deputi Bidang Pengawasan Penyelenggaraan Keuangan Daerah.

Krah, R.D.Y. and Mertens, G., 2020. Transparency in Local Governments: Patterns and Practices of Twenty-first Century. State and Local Government Review.

Kumalasari, D. and Riharjo, I.B., 2016. Transparansi dan akuntabilitas pemerintah desa dalam pengelolaan alokasi dana desa. Jurnal Ilmu dan Riset Akuntansi (JIRA), 5(11).

Kustono, A.S., Purnamasari, P. and Supatmoko, D., 2017. Akuntabilitas Pengelolaan Alokasi Dana Desa Di Desa Ledokombo Kecamatan Ledokombo Kabupaten Jember Tahun 2015. e-Journal Ekonomi Bisnis dan Akuntansi, 4(2), pp.141-147.

Liando, L.Y., Lambey, L. and Wokas, H.R., 2017. Analisis Pengelolaan dan Pertanggungjawaban Anggaran Pendapatan dan Belanja Desa di Desa Kolongan Kecamatan Kombi Kabupaten Minahasa. Jurnal EMBA: Jurnal Riset Ekonomi, Manajemen, Bisnis dan Akuntansi, 5(2).

Muda, I., Harahap, A.H., Erlina, S.G., Maksum, A. and Abubakar, E., 2018, March. Factors of quality of financial report of local government in Indonesia. In IOP Conference Series: Earth and Environmental Science (Vol. 126, No. 1, p. 012067).

Ruvalcaba-Gomez, E.A., 2019. Open Government and Citizen Participation: Perceptions between Civil Society Organizations and Government. JeDEMeJournal of eDemocracy and Open Government, 11(2), pp.1-13.

Sa'adah, B., 2015. Akuntabilitas Dan Transparansi Anggaran Melalui E-Government (Studi tentang Penganggaran di Pemerintahan Daerah Kabupaten Blitar). Jurnal Kebijakan Dan Manajemen Publik, 3, pp.1-10.

Sulumin, H.H., 2015. Pertanggungjawaban penggunaan alokasi dana desa pada pemerintahan desa di Kabupaten Donggala. Katalogis, 3(1).

Volta, C.A., 2019. Local Open Government Model for Rural Municipalities: Opportunities and barriers from the experience of Calle Larga. eJournal of eDemocracy \& Open Government, 11(2). 